\title{
SIKAP MAHASISWA PRODI PENDIDIKAN BAHASA ARAB TERHADAP PENERAPAN PEMBELAJARAN SECARA ONLINE DI MASA PANDEMI COVID-19
}

\author{
Nur Habibisaid ${ }^{1}$, Husna $^{1}{ }^{*}$, Alim Maghfur ${ }^{1}$ \\ ${ }^{1}$ Pascasarjana UIN Maulana Malik Ibrahim Malang
}

\begin{abstract}
This study aims to determine the attitudes of Arabic language education study program students towards the application of online learning during the Covid 19 pandemic. The study used a qualitative approach. Data were collected using interview techniques (structured and semi-structured), and documentation. There are three questions to be addressed: Agree and disagree, the obstacles faced and the enthusiasm of students towards the application of online learning. Of the 85 students who were asked through structured interviews using a questionnaire, it was found that as many as $60 \%$ of students expressed their agreement with the application of online learning. The obstacles faced when learning online are limited internet quota and signal or network constraints. The enthusiasm of students in participating in online learning is caused by fear of the spread of the corona virus. If the online learning process is continued in the future, students hope that it will only be a supporter and more agree with face-to-face learning as the main thing.
\end{abstract}

Keywords: student attitude, online learning, student enthusiasm

*Korespondensi Penulis: husnamawla@gmail.com 


\begin{abstract}
Abstrak: Penelitian ini bertujuan untuk mengetahui sikap mahasiswa prodi pendidikan bahasa Arab terhadap penerapan pembelajaran secara online di masa pandemi covid 19. Penelitian menggunakan pendekatan kualitatif. Data dikumpulkan dengan teknik wawancara (terstruktur dan semi terstruktur), dan dokumentasi. Terdapat tiga pertanyaan yang ingin diungkap: Sikap setuju dan tidak setuju; kendala yang dihadapi dan antusiasme mahasiswa terhadap penerapan pembelajaran online. Dari 85 mahasiswa yang ditanyai melalui wawancara terstruktur menggunakan angket, didapatkan data bahwa sebanyak 60\% mahasiswa menyatakan sikap setujunya terhadap penerapan pembelajaran secara online. Kendala yang dihadapi saat pembelajaran online adalah keterbatasan kuota internet dan kendala sinyal atau jaringan. Antusiasme mahasiswa mengikuti pembelajaran online disebabkan karena takut akan penyebaran virus corona. Bila proses pembelajaran online dilanjutkan pada masa mendatang, mahasiswa berharap hanya sebagai pendukung dan lebih setuju pada pembelajaran tatap muka sebagai yang utama.
\end{abstract}

\title{
Kata Kunci: sikap mahasiswa, pembelajaran online, antusiasme mahasiswa
}

\section{A. Pendahuluan}

Dikala ini umat manusia lagi terletak dalam kesedihan yang mendalam dikarenakan adanya wabah penyakit yang di sebut dengan Corona Virus Disease (Covid- 19) yang menyerang nyaris diberbagai belahan dunia. Di duga adanya Covid- 19 ini bermula mencuat awal kali di Wuhan Tiongkok, Provinsi Hubei, Cina, virus ini timbul sebab terdapatnya suatu pasar santapan di Wuhan yang menjual bermacam tipe hewan hidup ataupun telah mati. Virus ini sudah tersebar di segala dunia, tercantum di Indonesia semenjak dini bulan Maret. Serta sudah diumumkan bagaikan Pandemic oleh organisasi kesehatan dunia.

Kemdikbud RI memutuskan kalau segala aktivitas pendidikan baik di sekolah ataupun di akademi besar dilaksanakan di rumah tiap- tiap lewat aplikasi yang ada. Menteri pembelajaran menghasilkan Pesan Edaran No 3 Tahun 2020 
Tentang Penangkalan Corona Virus ( Covid- 19) Pada Satuan Pembelajaran yang melaporkan kalau meliburkan sekolah serta akademi besar. Salah satunya dengan mempraktikkan kebijakan belajar dari rumah, bekerja dari rumah, dan beribadah di rumah. Kebijakan berbagai Negara termasuk Indonesia dalam menghadapi masalah virus corona tersebut adalah dengan spontan menerapkan dengan adanya kebijakan belajar dari rumah, bekerja dari rumah, dan beribadah di rumah. ${ }^{1}$ Begitu juga kebijakan yang diterapkan dalam sistem pembelajaran di Perguruan Tinggi Institut Agama Islam Negeri Palangka Raya.

Institut Agama Islam Negeri Palangka Raya, dalam menghadapi masalah Covid-19, menerapkan sistem pembelajaran perkuliahan secara online untuk kebijakan belajar dari rumah. Tanpa kecuali di Prodi Pendidikan Bahasa Arab. Bagi Isman, pendidikan online ialah pemanfaatan jaringan internet dalam proses pendidikan. Dengan pendidikan online mahasiswa mempunyai keleluasaan waktu belajar, bisa belajar kapanpun dan dimanapun. Mahasiswa bisa berhubungan dengan dosen memakai sebagian aplikasi semacam google classroom, zoom, serta whatsapp group. Pendidikan ini ialah inovasi pembelajaran buat menanggapi tantangan hendak ketersediaan sumber belajar yang variatif. Keberhasilan sesuatu model maupun media pendidikan bergantung dari ciri partisipan didiknya. Sebagaimana yang diungkapkan oleh Nakayama serta Yamamoto, dari seluruh litelatur dalam e- learning mengindikasikan kalau tidak seluruh partisipan didik hendak sukses dalam pendidikan online. Ini disebabkan aspek area belajar serta ciri partisipan didik. ${ }^{2}$

Sejak diterapkannya sistem pembelajaran perkuliahan secara online ini muncul berbagai sikap dari mahasiswa,sikap yang muncul merupakan kesiapan seseorang untuk memberi tanggapan atau menilai suatu keadaan yang terarah

${ }^{1}$ Asmaul Khusna, Ni Putu Dyana, dan Lukman Arif, "Persepsi Siswa Terhadap Sistem Pembelajaran Daring Di SMP Muhammadiyah 1 Sidoarjo," Prosiding Konferensi Nasional Administrasi Negara Sinagara 2020, 2020, hlm. 2.

2 Khusna, Dyana, dan Arif, "Persepsi Siswa Terhadap Sistem Pembelajaran Daring Di SMP Muhammadiyah 1 Sidoarjo." 
pada suatu objek. Menurut Jogiyanto, perilaku ( attitude) merupakan penilaian keyakinan( beliefs) ataupun perasaan positif ataupun negatif dari seorang bila hendak melaksanakan sikap yang hendak didetetapkan. Sedangkan Fishbein serta Ajzen mendefinisikan kalau perilaku( attitude) bagaikan jumlah dari afeksi ataupun perasaan yang dialami seorang buat menerima ataupun menolak sesuatu objek ataupun sikap serta diukur dengan sesuatu prosedur yang menepatkan individual pada skala evaluatif, misalnya baik ataupun kurang baik, menerima ataupun menolak, serta yang lain. Jadi perilaku dalam data ini memastikan baik ataupun buruknya sesuatu sistem. ${ }^{3}$

Berdasarkan observasi awal penulis, kepada mahasiswa prodi pendidikan bahasa Arab di Institut Agama Islam Negeri Palangka Raya, didapatkan hasil wawancara dengan Elis Tania, menunjukkan bahwa Dia merasa tidak senang dengan adanya penerapan pembelajaran secara online. Dia mengungkapkan bahwa penerapan pembelajaran secara online dirasa susah, dikarenakan jaringan internet yang tidak mendukung, apalagi bagi mahasiswa yang sedang berada di kampung yang tidak terdapat sinyal atau jaringan internet disana. Berbeda halnya dengan tanggapan Mirza Mahfud, mahasiswa pendidikan bahasa Arab lainnya. Dia merasa senang dengan adanya penerapan pembelajaran secara online. Dia mengungkapkan bahwa penerapan pembelajaran secara online sangat membantu ditengah wabah covid-19 ini yang mengharuskan agar tetap menjaga jarak (sosial distancing) dalam pelaksanaan pembelajaran. Karena pembelajaran online tersebut bisa dilakukan kapanpun, dimanapun, dan lebih santai daripada harus tatap muka yang mengharuskan masuk kuliah di dalam kelas. Sementara dari pihak institusi,kegiatan belajar mengajar harus berjalan dengan baik sesuai pemberlakuan psyhcal distancing yaitu belajar dari rumah.

${ }^{3}$ Alfin Lutfi Aziz, "Pengaruh Kemudahan Penggunaan Terhadap Kemanfaatan Pada Sikap Pengguna E-learning Survei Pada Mahasiswa Jurusan Administrasi Bisnis, Fakultas Ilmu Administrasi Universitas Brawijaya Malang Angkatan 2011," Jurnal Administrasi Bisnis 6, no. 2 (2013). 
Berdasarkan kajian pendahuluan tersebut, peneliti tertarik untuk meneliti sikap mahasiswa pendidikan bahasa Arab. Peneliti ingin mengetahui lebih dalam lagi masalah sikap mereka, baik yang positif maupun negatif. Positif yang dimaksud ialah setuju, sedangkan negatif, tidak setuju. Maka pada kajian ini, peneliti bermaksud mengungkap kesetujuan atau ketidak setujuan, berbagai kendala yang dihadapi serta antusiasme mahasiswa dalam penerapan pembelajaran secara online.

\section{B. Kajian Literatur}

\section{Pengertian, Ciri, Fungsi dan Pengukuran Sikap}

Menurut Azwar, ${ }^{4}$ perilaku merupakan salah satu faktor karakter yang wajib dipunyai seorang buat memastikan tindakannya serta bertingkah laku terhadap sesuatu objek diiringi dengan perasaan positif serta negatif. Setelah itu para ahli psikologi mendisfungsikan sesuatu perilaku merupakan sesuatu wujud penilaian ataupun respon perasaan. Serta perumusan sesuatu perilaku itu berhubungan bagaikan afek positif serta afek negatif yang berhubungan dengan sesuatu objek psikologis. Jadi perilaku itu berhubungan dengan perasaan seseorang terhadap objek bukan aksi, dimana terdapat kalanya positif serta terdapat kalanya negatif.

Menurut Jogiyanto, ${ }^{5}$ bahwa sikap (attitude) adalah evaluasi kepercayaan (beliefs) atau dengan adanya perasaan postif dan negatif dari seseorang jika akan melakukan perilaku atau perbuatan yang akan di tentukan. Sementara menurut Ajzen dan Fishbein mengartikan bahwa sikap (attitude) sebagai jumlah dari afeksi atau perasaan yang dirasakan seseorang untuk menerima ataupun menolak suatu objek dari perilaku dan dapat diukur melalui suatu prosedur yang menempatkan individual pada skla evaluatif, misalnya baik atau buruk, menerima atau menolak,

4 Dalam Yayat Suharyat, "Hubungan antara sikap, minat dan perilaku manusia," Jurnal Region 1, no. 3 (2009): hlm. 4.

5 Dalam Aziz, "Pengaruh Kemudahan Penggunaan Terhadap Kemanfaatan Pada Sikap Pengguna E-learning Survei Pada Mahasiswa Jurusan Administrasi Bisnis, Fakultas Ilmu Administrasi Universitas Brawijaya Malang Angkatan 2011.” 
dan lainnya. Jadi sikap dalam informasi ini menentukan dari segi baik baik atau buruknya suatu sistem. Dan komponen-komponen sikap terdiri dari tiga komponen yang saling menunjang yaitu komponen, afektif (komponen emosional), kognitif(tindakan)dan komponen konatif (penilaian). ${ }^{6}$

Sikap menentukan jenis atau tabiat tingkah laku dalam hubungannya dengan perangsang yang relevan, orang-orang atau kejadian-kejadian. Dapatlah dikatakan bahwa sikap merupakan faktor internal, tetapi tidak semua faktor internal adalah sikap.7 Adapun ciri-ciri sikap yaitu, Sikap dapat berubah-ubah, Sikap tidak berdiri sendiri, Sikap berupa berupa kumpulan dari sesuatu hal dan Terdapat segi-segi motivasi dan perasaan. Faktor-faktor yang mempengaruhi munculnya suatu sikap pada diri seseorang, di antaranya adalah: Penyesuaian diri, ketahanan diri, pengekspresian nilai dan Pengetahuan.

Untuk mengenali perilaku dan sikap seorang, maka dibutuhkan suatu pengukuran terhadapnya, dan penarikan kesimpulan dari tanggapan serta anggapan masyarakat sebagai objek penelitian, sehingga dapat merumuskannya. Metode pengukuran prilaku dan sikap tersebut dengan menggunakan skala sikap, yaitu dengan:

a. Pengukuran sikap secara langsung tidak terstruktur. Artinya dalam pengukuran ini tidak menggunakan pengukuran sikap secara terstruktur. Dengan cara ini dapat dikatakan dalam cara sederhana, karena seorang peneliti tidak harus mempersiapkan komponennya secara mendalam untuk mengukur sikap tersebut. Namun hasil yang akan dicapai atau di peroleh kurang maksimal, karena cara ini lebih kepada ranah pengetahuan sikap dari objek penelitian.

b. Pengukuran sikap secara langsung yang terstruktur. Untuk cara pengukuran dalam sikap jenis ini dengan menggunkan skala pengukuran, ada beberapa yang bisa digunakan yaitu dengan Skala R. Likert, digunakan buat mengukur

\footnotetext{
${ }^{6}$ Saifuddin Azwar, Sikap Manusia Teori dan Pengukurannya (Yogyakarta: Pustaka Pelajar Offset, 2007), hlm 24.

${ }^{7}$ Ahmadi, Ilmu pendidikan (suatu pengantar) (Salatiga: CV Saudara, 2013), hlm. 178.
} 
pendapat, sikap, dan asumsi seseorang maupun sekelompok orang menegenai akan gejala atau fenomena tertentu. Ada terdapat 2 yang termasuk dalam Likert ini yakni bentuk positi dan negatif. Positif untuk mengukur sikap positif dan negatif untuk mengukur sikap negatif. Skala likert ini dapat di ketahui dengan summated rating, karena dengan perhitungan nilai ataupun skor responden pada skala ini dengan menjumlahkan asumsi yang diberikannya.

\section{Pembelajaran Online/ E-Learning}

Pembelajaran online atau yang biasa disebut dengan E-Learning merupakan teknologi pembelajaran yang diterapkan di dunia pendidikan dalam bentuk dunia maya atau tidak langsung. Istilah e-learning lebih tepatnya dimaknai dengan proses transformasi pembelajaran tradisional menuju pembelajaran modern. Penerapan e-learning mengubah proses pembelajaran disekolah ataupun perguruan tinggi dari manual menjadi bentuk digital dengan dijembatani teknologi internet. ${ }^{8}$ Sedangkan menurut Effendi ${ }^{9}$ terminologi e-learning mengacu kepada setiap kegiatan pembelajaran yang menggunakan media elektronik. E-learning terdiri atas dua bagian yaitu "e" yang berarti elektronik dan learning bermakna pembelajaran. Jadi, e-learning dapat diartikan sebuah pembelajaran dengan penggunaan perangkat elektronik khususnya computer dan internet. Oleh sebab itu e-learning biasa disebut juga dengan online course atau pembelajaran.10

Pembelajaran online merupakan sebuah sistem yang dilaksanakan dengan pemanfaatan media elektronik untuk menunjang proses pembelajaran. Sebagian besar berpendapat bahwa pembelajaran online lebih mengarh kepada penggunaan computer/ laptop dengan menggunakan jaringan internet.11

8 Poppy Yaniawati, E-Learning Alternatif Pembelajaran Kontemporer (Bandung: Arfino Raya, 2010), hlm. 169.

9 Empy Effendi dan Hartono Zhuang, E-learning Konsep dan Aplikasi (Yogyakarta: Penerbit Andi, 2005), hlm. 6.

${ }^{10}$ Effendi dan Zhuang, hlm. 73.

11 Dewi Salma Prawiradilaga, Mozaik Teknologi Pendidikan: E-Learning (Kencana, 2016), hlm. 168. 
Berdasarkan dari beberapa pendapat diatas terkait pengertian pembelajaran online atau e-learning dapat disimpulkan bahwa pembelajaran online adalah sebuah proses pembelajaran jarak jauh atau daring dengan menggunakan media elektronik berupa computer dengan dukungan internet. Pembelajaran online tidak terbatas dan terhalangi oleh ruang dan waktu. Hal ini dikarenakan pembelajaran online dapat dilaksanakan di mana saja dan kapan saja asalkan terdapat jaringan internet untuk mengaksesnya.

\section{E-Learning Sebagai Komplemen Pembelajaran Konvensional}

Dalam pelaksanaannya, e-learning mempunyai beberapa kegunaan. Manfaat e-learning terhadap aktivitas pendidikan di dalam kelas, salah satunya merupakan bagaikan komplemen aksesoris pendidikan konvesional. Tidak hanya berperan bagaikan komplemen, e- learning pula berperan bagaikan suplemen ( bonus) subtisusi (pengganti). Dikatakan berperan bagaikan komplemen (aksesoris/ pendukung) apabila modul pendidikan elektronik diprogramkan buat memenuhi modul yang diperoleh oleh mahasiswa dalam forum kuliah. Artinya jika terdapat mahsiswa yang dihadapi kesusahan dalam menguasai modul pelajaran yang diberikan dosen secara tatap muka di dalam kelas, maka harus diberikan peluang buat menggunakan modul pendidikan elektronik. Tujuannya supaya mahasiswa terus menjadi lebih gampang menguasai modul pelajaran yang disajikan oleh dosen di kelas.

Adapun manfaat lain dari adanya E- Learing ini, dapat dirinci sebagai berikut:

a. Memudahkan serta menaikkan waktu interaksi mahasiwa dengan belajar dan interaksi antara mahasiwa dengan dosen ataupun juga antar mahasiswa.

b. Membolehkan untuk mahasiswa buat senantiasa bisa belajar sekalipun tidak bisa berhadir secara langsung ketika berada dalam kelas. Aktivitas dalam belajar membuat sangat fleksibel sebab menyesuaikan dengan ketersediaanya 
waktu para mahasiswa. Sehingga terjalin interaksi pendidikan dari mana saja serta kapan saja.

c. Membolehkan mahasiswa ataupun dosen bisa silih berbagi data ataupun komentar tentang modul kuliah sehingga bisa memaksimalkan waktu tatap muka yanag ada buat konsentrasi pada modul tersebut.

d. Tingkatkan mutu serta kinerja seorang dosen dengan adanya pengembanagn model- model pendidikan yang lebih baik serta bahan beljar yang lebih mudah ketika dipelajari, dipahami dan dapat dimengerti oleh mahasiswa.

e. Kurangi kesenjangan digital antara dosen dan mahasiswa dengan menerapkan suatu sistem yang berbasis teknologi internet secara terpadu dan terintegrasi.

f. Mempemudah penyempuranaan serta penyimpanan bahan belajar.

\section{Kekurangan dan Kelebihan E- Learning}

Dari bermacam pengalaman serta pula dari berbagai macam data yang adanya literatur, membagikan petunjuk tentang adanya khasiat pemakaian internet, spesialnya dalam pembelajaran terbuka dan juga jark jauh, antara lain bagaikan berikut:

a. Tersedianya sarana e-moderating di mana dosen serta mahasiswa bisa berbicara secara mudah lewat sarana internet secara regular, kapan saja.

b. Antara Dosen dan mahasiswa dapat menggunakan bahan ajar dengan petunjuk belajar yang terstruktur serta terjadwaal melalui internet.

c. Mahasiswa bisa belajar ataupun mengulang kembali bahan ajar tiap dikala serta di mana saja jika dibutuhkan mengingat bahan ajar tersimpan di pc.

d. Apabila mahasiswa mencari materi yang berkaitan dengan apa yang sedang dipelajarinya, dia dapat dengan mudah mengakses di internet.

e. Baik dosen ataupun mahasiswa bisa melaksanakan dialog lewat internet yang bisa diiringi dengan jumlah partisipan yang banyak, sehingga menaikkan ilmu pengetahuan serta pengetahuan yang lebih luas.

f. Berubahnya kedudukan mahasiswa dari yang umumnya pasif jadi aktif. 
Adapun kekurangannya, antara lain bagaikan berikut: a) Minimnya interaksi antara dosen dan mahasiswa; b) Cenderung mengabaikan aspek akademik; c) Proses belajar serta mengajarnya lebih mengarah pada pelatihan dibanding pembelajaran; d) Membuat dosen dari yang semula memahami metode pendidikan konvensional, saat ini pula diharuskan mengenali metode pendidikan dengan memakai ICT; e) Sebagian dari mahasiswa merasa tidak memiliki motivasi belajar yang besar; f) Tidak seluruh tempat ada sarana internet dikarenakan berkaitan dengan permasalahan tersedianya listrik, telepon maupun pc di daerah tertentu.

Dari sebagian kekurangan yang sudah sampaikan, kekurangan itu dapat di atasi dengan pemanfaatan e-learning sebatas bagaikan sistem pendukung bukannya bagaikan sistem pengganti. Dengan kekurangan tersebut, diharapkan bisa jadi acuan untuk tingkatkan mutu pembelajaran.

\section{Konsep Pembelajaran Berbasis E-Learning}

Implementasi internet dalam dunia pendidikan mempermudah kegiatan perkuliahan, seperti seorang mahasiswa yang ingin melihat nilainya secara online, melihat jadwal kuliah, mengirim berkas tugas, dan sebagainya. Contohnya pada interaksi pendidikan antar dosen serta mahasiswa, seseorang dosen yang tidak bisa muncul/ mengajar di kampus, hendak menyuruh mahasiswanya buat menekuni modul perkuliahan pada web dosen tersebut, ataupun si dosen hendak menyuruh mahasiswanya buat mendownload modul perkuliahan, ataukah si dosen hendak mengadakan video conference dengan mahasiswanya buat melaksanakan aktivitas pendidikan. Seluruh ini ialah konsep pendidikan Elearning yang tidak terlepas antara dosen serta mahasiswa, guru serta murid, pengajar serta pembelajar, tanpa memahami tempat serta waktu. ${ }^{12}$

12 Rabiah Adawi, "Pembelajaran Berbasis E-Learning," Fakultas Bahasa dan Seni Universitas Negeri Medan, 2008, hlm. 3. 
Metode belajar lewat website ( E- learning) ketentuan utama yang wajib dipadati ialah terdapatnya akses dengan sumber data lewat internet. Berikutnya terdapatnya data dimana letak sumber data yang mau kita miliki. Terdapat sebagian sumber informasi yang bisa diakses dengan leluasa serta free tanpa proses administrasi serta pengaksesan yang rumit. Dan terdapat sebagian sumber data yang cuma diakses oleh pihak yang memanglah sudah diberi otorisasi owner sumber data. Mewujudkan pendidikan berbasis website bukan hanya meletakkan modul belajar pada website setelah itu diakses lewat pc, website digunakan bukan cuma bagaikan media alternatif pengganti kertas buat menaruh bermacam dokumen ataupun data. Website digunakan buat memperoleh sisi unggul yang tidak dipunyai kertas ataupun yang lain. Pendidikan berbasis website itu unik tetapi sungguh- sungguh, yang diartikan sungguh- sungguh disini merupakan merancang hingga dengan mengimplementasikan pendidikan berbasis website tidak semudah yang dibayangkan. Tidak hanya infrastruktur internet, Pendidikan berbasis website membutuhkan suatu model instruktur yang memanglah dirancang spesial buat keperluan pendidikan. ${ }^{13}$

\section{Metode Penelitian}

Pendeketan pada penelitian ini menggunakan penelitian kualitatif-deskriptif. Subjek pada penelitian ini adalah Mahasiswa Prodi Pendidikan Bahasa Arab Institut Agama Islam Negeri Palangka Raya yang berjumlah (85) orang. Semester/Angkatan II/ 2019 Jumlah Mahasiswa (38), Semester/Angkatan II/ 2019 Jumlah Mahasiswa (30), dan Semester/Angkatan II/ 2019 Jumlah Mahasiswa (17).

Teknik pengumpulan data dilakukan dengan wawancara (tersruktur dan semi tersruktur) dan dokumentasi. Wawancara terstruktur dilakukan menggunakan instrumen angket. Penggunaan instrumen dimaksudkan untuk untuk memperoleh data yang akurat pada suatu fenomena sosial yang meliputi pengukuran komponen suatu sikap, pendapat, dan persepsi individu ataupun

\footnotetext{
${ }^{13}$ Adawi, hlm. 3.
} 
kolektif masyarakat. ${ }^{14}$ Partisipan akan diminta untuk menyampaikan pendapatnya dengan memilih jawaban (1) setuju dan (2) tidak setuju, atas penerapan pembelajaran secara online di masa pandemi covid-19 tahun ajaran 2019/2020. Dari hasil jawaban angket tersebut, akan dilakukan interview lanjutan (wawancara semi terstruktur) dengan beberapa partisipan, melalui teknik snowball sampling. Interview dimaksudkan untuk mengungkap alasan kesetujuan atau ketidak setujuan, kendala yang mereka hadapi serta antusiasme mereka terhadap pembelajaran secara online tersebut.

Selanjutnya, teknik analisis data digunakan analisis deskriptif, yaitu suatu teknik untuk mengungkapkan dan memaparkan pendapat dari partisipan berdasarkan jawaban dari instrumen penelitian yang telah diajukan peneliti. Dalam penelitian ini, analisis deskriptif digunakan untuk menganalisis perolehan skor dari angket. ${ }^{15}$

\section{c. Hasil dan Pembahasan}

Berdasarkan paparan data hasil wawancara, angket dan dokumentasi, terdapat empat komponen yang menjadi hasil penelitian: 1) Mahasiswa yang Setuju Terhadap Penerapan Pembelajaran Secara Online Di Masa Pandemi Covid 19, 2) Mahasiswa yang Tidak Setuju Terhadap Penerapan Pembelajaran Secara Online Di Masa Pandemi Covid 19, 3) Kendala yang dihadapi ketika pembelajaran secara Online dan 4) Antusiasme mahasiswa terhadap penerapan pembelajaran secara online yang akan berkelanjutan.

\section{Mahasiswa yang Setuju Terhadap Penerapan Pembelajaran Online}

Berdasarkan data dari hasil penelitian yang diperoleh, dapat disimpulkan bahwa beberapat dari mereka setuju atau senang dengan penerapan pembelajaran secara online. Alasan yang terungkap adalah karena adanya pemahaman bahwa salah satu cara untuk mencegah penyebaran penyakit menular ini, adalah

\footnotetext{
${ }^{14}$ Sugiyono, Metode penelitian pendidikan (Bandung: Alfabeta, 2014), hlm. 134.

15 Sugiyono, hlm. 147.
} 
dilakukannya Sosial Distancing (pembatasan jarak sosial). Dalam kondisi pandemi, sangat tidak memungkinkan bagi mereka untuk melaksanakan kegiatan belajar mengajar didalam kelas atau bertatap muka secara langsung, sehingga penerapan pembelajaran secara online sangat benar dan harus dilakukan agar proses pembelajaran bisa terlaksana dan harus mengikuti anjuran atau aturan yang telah ditentukan. Secara prosentase, terdapat 59,67\% (60\%) mahasiswa yang menyatakan setuju dengan penerapan pembelajaran secara online di masa pandemi.

\section{Mahasiswa yang Tidak Setuju terhadap Penerapan Pembelajaran Online}

Berdasarkan hasil wawancara, bahwa sikap beberapa mahasiswa prodi pendidikan bahasa Arab terhadap penerapan pembelajaran secara online di Masa Pandemi Covid 19 menunjukkan ketidaksetujuannya atau tidak senang dengan pembelajaran online. Alasan yang terungkap karena dirasa kurang efektif dan juga banyaknya kesulitan dan kendala yang dihadapi mereka dalam menerima pembelajaran apalagi pada prodi mereka yakni pendidikan bahasa, yang mana harusnya keaktifan mereka sebagai seorang calon guru lebih diutamakan beraktivitas secara langsung atau aktif berinteraksi di dalam kelas. Penerapan pembelajarannya secara online menyebabkan mereka merasa ilmu yang mereka dapat itu tidak sempurna, hanya dalam segi materi pembelajaran yang mereka dapat tanpa langsung dipraktekkan. Akan tetapi, dalam keadaan pandemi mau tidak mau mereka harus menjalaninya agar proses belajar mengajar tetap terlaksana sesuai prosedur yang sudah ditentukan dan memanfaatkan segala sesuatu dengan baik dan juga benar walaupun masih banyak kekurangan dalam pembelajaran secara online. Data yang diperoleh dari hasil sebaran angket menunjukkan terdapat sekitar 40\% yang menyatakan ketidaksetujuannya. Mahasiswa prodi pendidikan bahasa Arab menemukan kesulitan dalam pembelajaran secara online. 


\section{Kendala yang Dihadapi Ketika Pembelajaran Secara Online}

Ada beberapa kendala yang dihadapi dan dirasakan mahasiswa ketika pembelajaran secara online yaitu dari segi faktor ekonomi dan geografis (tempat tinggal) contoh kendala yang dirasakan seperti harus memiliki kouta atau paket data internet untuk bisa mengikuti pembelajaran secara online, dan susah sinyal atau jaringan.

Berdasarkan data dari hasil penelitian yang diperoleh, dapat disimpulkan bahwa sikap mahasiswa prodi pendidikan bahasa Arab terhadap penerapan pembelajaran secara online di Masa Pandemi Covid 19 sebenarnya tidak setuju atau tidak senang dikarenakan banyaknya kendala dan kesulitan yang dihadapi mereka ketika pembelajaran secara online. Kendala yang dihadapi mereka adalah dari segi ekonomi yang mana mereka harus mempunyai paket data untuk bisa mengikuti pembelajaran secara online, dan kendala selanjutnya ketika pembelajaran secara online, interaksi antara dosen dan mahasiswa sering terjadi miskomunikasi, terkadang antara jam masuk kuliah sering bertabrakan dengan mata kuliah yang lain sehingga akhirnya hanya tugas yang akan diberikan dosen ketika hal seperti itu terjadi. Selain itu juga mahasiswa bingung untuk mencari refrensi cuma hanya di google. Yang lebih kasihan lagi bagi mahasiswa yang berada di daerah-daerah terpencil yang terbatas untuk mengakses internet karena tidak semua daerah memiliki jaringan yang baik, sehingga pembelajaran secara online menjadi terhalang.

\section{Antusiasme Mahasiswa Terhadap Penerapan Pembelajaran Secara Online yang Berkelanjutan}

Dari hasil wawancara kepada mahasiswa prodi pendidikan bahasa Arab, ada beragam respon antusiasme mahasiswa prodi pendidikan bahasa Arab terhadap penerapan pembelajaran secara online yang akan berkelanjutan. Ada yang siap atau mendukung dan ada juga yang tidak siap atau tidak mendukung untuk menghadapi pembelajaran secara online tersebut. 
Berdasarkan data dari hasil penelitian yang diperoleh, dapat disimpulkan bahwa ketika wabah covid berakhir, kalau untuk mendukung proses belajar mengajar mereka siap dengan penerapan pembelajaran secara online, asalkan tidak semua pembelajaran harus mereka lakukan dengan pembelajaran online karena pembelajaran bertatap muka dikelas secara langsung dengan pembelajaran secara online sangat jauh berbeda dan dalam pembelajaran secara online pun masih sangat banyak terdapat kekurangan dan kendalanya. Mahasiswa lebih menyukai pembelajaran bertatap muka secara langsung didalam kelas daripada pembelajaran secara online.

\section{Kesimpulan}

Hasil penelitian menunjukkan bahwa sikap mayoritas (60\%) mahasiswa prodi pendidikan bahasa Arab terhadap penerapan pembelajaran secara online di Masa Pandemi Covid 19, tahun ajaran 2019/2020 di Institut Agama Islam Negeri Palangka Raya Fakultas Tarbiyah dan Ilmu Keguruan adalah tidak setuju. Alasan kesetujuan tersebut adalah karena dapat mengurangi penyebaran wabah covid 19 . Hasil ini memiliki implikasi di mana para pengelola pendidikan perlu menyadari bahwa penerapan pembelajaran online hanya merupakan solusi atas adanya musibah. Mahasiswa setuju yaitu dalam hal yang negatif, yang mana mereka menyatakan setuju bukan karena penerapan pembelajaran secara online, akan tetapi mereka mau tidak mau setuju karena, mereka takut akan penyebaran virus corona. Sebagian mahasiswa justru menyatakan tidak setuju karena mereka memiliki beberapa kendala yang dihadapi dan dirasakan ketika pembelajaran secara online yaitu dari segi faktor ekonomi dan geografis (tempat tinggal), seperti masalah kuota dan jaringan yang lemah. Mahasiswa tidak begitu antusias jika pembelajaran online dilaksanakan secara berkelanjutan dalam kondisi normal. 


\section{Daftar Rujukan}

Adawi, Rabiah. "Pembelajaran Berbasis E-Learning." Fakultas Bahasa dan Seni Universitas Negeri Medan, 2008.

Ahmadi. Ilmu pendidikan (suatu pengantar). Salatiga: CV Saudara, 2013.

Aziz, Alfin Lutfi. "Pengaruh Kemudahan Penggunaan Terhadap Kemanfaatan Pada Sikap Pengguna E-learning Survei Pada Mahasiswa Jurusan Administrasi Bisnis, Fakultas Ilmu Administrasi Universitas Brawijaya Malang Angkatan 2011." Jurnal Administrasi Bisnis 6, no. 2 (2013).

Azwar, Saifuddin. Sikap Manusia Teori dan Pengukurannya. Yogyakarta: Pustaka Pelajar Offset, 2007.

Effendi, Empy, dan Hartono Zhuang. E-learning Konsep dan Aplikasi. Yogyakarta: Penerbit Andi, 2005.

Khusna, Asmaul, Ni Putu Dyana, dan Lukman Arif. "Persepsi Siswa Terhadap Sistem Pembelajaran Daring Di SMP Muhammadiyah 1 Sidoarjo." Prosiding Konferensi Nasional Administrasi Negara Sinagara 2020, 2020.

Prawiradilaga, Dewi Salma. Mozaik Teknologi Pendidikan: E-Learning. Kencana, 2016.

Sugiyono. Metode penelitian pendidikan. Bandung: Alfabeta, 2014.

Suharyat, Yayat. "Hubungan antara sikap, minat dan perilaku manusia." Jurnal Region 1, no. 3 (2009): 1-19.

Yaniawati, Poppy. E-Learning Alternatif Pembelajaran Kontemporer. Bandung: Arfino Raya, 2010. 